Wacana Vol. 20 No. 3 (2019): 507-524

\title{
Money and masohi
}

\section{An anthropological review of copra commodity management}

\author{
TONY RUDYANSJAH AND ODE Z.S. TIHURUA
}

\begin{abstract}
In discussions on exchange, as well as an object in gift exchange money is often seen as a medium of exchange and a universal equivalent in the circulation of commodities. However, in the case of the management of the copra commodity which we researched on the island of Seram, money had become a factor in shaping a dynamic of gift continuity and transformation in the realm of the copra economy (in this context of the customary practice masohi). It transpires that money has promoted both the observance and erosion of masohi custom. Masohi is a tradition of community work in the island of Seram. It is based on non-capitalist social relations and the principle of reciprocal exchange. This article seeks to describe how money, originally a capitalist medium, has simultaneously served to preserve and transform masohi, which, in its essence, is a non-capitalist institution.
\end{abstract}

KEYWORDS

Money; masohi custom; copra commodity; gifts.

\section{INTRODUCTION $^{1}$}

This article is an ethnography of the villagers of Yainuelo in Seram (see Map 1) in the Moluccas (Maluku), Indonesia, in a time after which commodity exchange and money had been introduced into this village. Too often, leftist scholars think that the logic of capitalism (surely, commodity exchange and money are the driving forces of capitalism) has taken over the world; and, therefore, there is no need to examine global connection ethnographically at the village level. These scholars tend to espouse the belief that capitalism

1 We are grateful to Clare Cameron, Rosemary Robson, and Professor Anna Tsing for correcting the English of this article as well as for giving this article the benefit of their fine critical eyes.

The authors can be reached at: tony.rudyansjah@ui.ac.id (TONY RUDYANSJAH), tihuruaz85@gmail.com (ODE ZULKARNAIN SAHJI TIHURUA). More information about the authors can be found at the end of the article.

(C) 2019 Faculty of Humanities, Universitas Indonesia

TONY RUdiAnsyah AND ODE Z.S. TIHURUA| DOI: 10.17510/wacana.v20i3.700. 
will ultimately replace and annul non-capitalist social relations. However, capitalism never transcends "primitive accumulation" (for example, gift exchange) but, rather, continues to depend on it. It is "primitive accumulation" which makes capitalism possible. Following Anna Tsing $(2005,2013)$, we argue that the process through which capitalism transforms social relations is not an easy one. The work must be repeated over and over again. Moreover, this process is fraught with hopes and despairs. One of the anthropologist's tasks is to record these as accurately as possible through detailed ethnographic research.

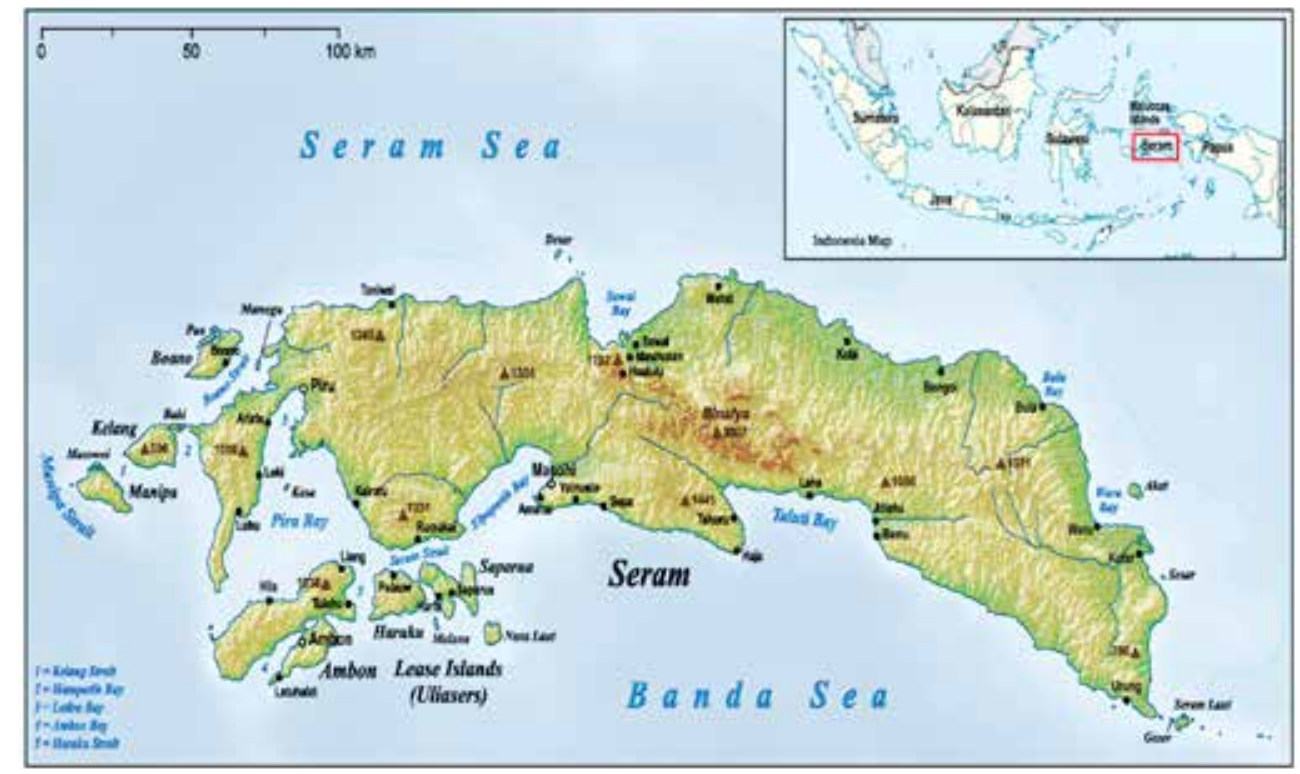

Map 1. Map of Seram Island (source: Wikimedia Commons, June 2015, modified by author. Retrieved from https://id.wikipedia.org/wiki/Berkas:Seram_en.png).

In the management of copra as a commodity in Yainuelo, money plays a dual role. On one hand, it functions as a tool to preserve the masohi tradition and, on the other, to erode this very tradition. Their growing need for cash encouraged farmers in Seram to accept cultivating copra as a commodity which they have managed with masohi traditions. ${ }^{2}$ In the early stages of copra acceptance, money was needed exclusively to meet certain specific needs like funding the Hajj pilgrimage, healthcare, or education. Although at one time simply required to meet these needs, the role of money grew, accelerating its circulation in the social lives of copra farmers. This is the stage at which money became an end in itself. Henceforth every activity in the life of the farmer was dedicated to making money. This switch transformed the management of the copra commodity, resulting in the erosion of masohi tradition.

2 Masohi is a practice in which people voluntarily pool their skills, energy, and money in order to perform a task which would otherwise exceed the capacity of any one individual or family. A more detailed and precise definition of masohi will be presented in later discussion. 
The dynamics of this relationship between money and masohi farmers and copra exposes a process which Kadir (2017: 36) refers to as "monetization". He defines monetization as a growth in the circulation and acceleration of the use of money in social life. In our ethnographic context, monetization occurs through the commodification of crops.

A woman from the village of Yainuelo, already \pm 65 years old, said, "Once money was hard [to come by] but life was happy, now money is easy to find but life is hard". Why was money hard to find but life happy? In our opinion, the reason is that the community's efforts were not previously entirely devoted to making money. They made only enough money to meet specific needs, allowing them ample free time to rest; tell and share stories with relatives, neighbours, and friends; and participate in other social activities, including involving themselves in masohi work. Nowadays the reverse is true, activities which generate income are now easy to come by, but meeting all their daily needs requires money. The upshot is that they must devote a great deal of their time making money. Nowadays as they are occupied with making money, people's free time is limited and the intensity of the storytelling and the sharing with each other has receded. As life's difficulties must now ultimately be borne alone, living has become more as an uphill battle. Money, which previously functioned as a medium for exchange used to meet specific needs (for example, for funding the Hajj pilgrimage), has become a fetish.

As each person or family spends significantly more time making money, the traditions of masohi work are increasingly being abandoned or have substantially diminished. At this point, the masohi tradition in the management of the copra commodity is in the throes of a transformation. One young child from the village of Sepa conveyed the following:

Once lots of people were involved in masohi work, not anymore now. If, however, many people help another person, his work will, of course, be helped by [those] others.

Bartels (2017: 245) refers to the masohi tradition as an expression of an idealized Maluku community collectivism which was once made manifest in many everyday tasks, but has now been swallowed up by the routine of making money. Social relations have become calculated. The villagers of Yainuelo count how much money must be spent per day and consider how to earn it. Consistent with this type of social transformation, Roy Ellen (2003: 141-143) emphatically suggests that intrusions from the West (especially those by the Dutch, Chinese, and Arabs) have resulted in the destabilization of the sosolot system among the Serammers. Sosolot is a trading institution based either on kinship links or maintained with places which have pre-established links. This trading institution is also part and parcel of masohi custom

This article is part of our desire to contribute to the long-debated anthropological discussion on the gift and commodity, which can be traced back at least as far as the work of Marcel Mauss (2002 [1954]). A more recent study on the gift was undertaken by Konstantinos Retsikas (2016). Retsikas 
repositions and offers a new perspective of the gift (in his case, soliciting in Java). If Mauss positioned the gift as a point of contrast to commodity production, and associated it with morality, reciprocity, civility and goodness. Retsikas, on the contrary, has unearthed elements of violence entailed in the act of soliciting in Java. What we want to address here is not just the complexity and ambiguity of the gift, but also of money as a medium of exchange, or commodity.

In Yainuelo, masohi represents gift exchange, while copra represents commodity exchange. In our view these two modes of exchange as not always at odds but, rather, in real life situations, always exist in relation to one another. Efforts to understand the relationship between gifts and commodities which ignore the role of money will always fall short, as the commodity and money can be thought of as two sides of the same coin. Trying to reach an understanding of the relationship between these two sides has encouraged us to ask: How does money play a role in both the preservation and erosion of masohi traditions as they relate to copra management? By examining the masohi tradition in the management of copra, we are able to trace how capitalist commodities gradually transform social relations within rural communities.

\section{RESEARCH METHODOLOGY}

In order to undertake this research, we began by conducting a search for materials, documents, and anthropological studies relevant to copra and Maluku, as well as of anthropological studies on commodities, gifts, and money. More simply, in this early stage of research, we conducted a "desk study". In our opinion, this pre-research stage is one of the most important aspects of ethnographic research. Besides these works, important documents published by the Indonesian government related to data on demographics, poverty, and the economy in Maluku were also referenced.

One of the key aspects of ethnography is participant-observation, in which the researchers observe while participating in the informants' activities. The researchers' involvement is crucial in determining whether the research process will go well and, importantly, relates to the development of rapport with informants. Besides participant-observation, we also found it important to conduct in-depth interviews using an open-ended question model.

The location of our research was Yainuelo village in the Island of Seram, Maluku, Indonesia. Yainuelo is currently an administrative village, but it was previously a hamlet within the village of Sepa. Although the village of Yainuelo is now administered autonomously, it still follows Sepa customary law. In the context of this research, it is impossible to discuss Yainuelo without referring to Sepa, whether in terms of social relations or culture. The population of Yainuelo consists of various ethnicities: around 30 percent indigenous to Sepa, 60 percent Butonese, and 10 percent Kei, Javanese, Buginese, and Timorese.

The village of Yainuelo is home to the co-author of this article. This begs the question, why did we choose his own village as a research site? The first reason was cultural urgency. Each time the co-author returned to his village 
and shared stories with relatives and the community there, they frequently complained about money. They are under a moral obligation to give hadiah, or gifts, in the form of money each time there is a celebration in the village. The hadiah to which we are referring exemplify the anthropological concept of the gift. They think that money is making life increasingly difficult. This was also how the co-author has sometimes felt. Despite an income considered meagre in the city, he must still send money each time there is a celebration in his village. Stories from the community, coupled with the experiences of the co-author, led us to wonder how it is that money, rather than other goods produced by the community, has become the requisite hadiah for each celebration?

The second reason for choosing Yainuelo as a research site is the compatibility of the research subject with the research location. Our research subject is the copra commodity and, hence, the research site selected needed to be a unit of society in which the economy depended heavily on the commodity of interest and cultural processes had already assembled around this economic activity. The economies of Sepa and Yainuelo villages have relied on the copra commodity since the mid-twentieth century. Furthermore, a unique and complex relationship exists between the commodity and the people. The requirements of copra management activities led people to make use of longheld masohi traditions. Moreover, copra management also led to the creation of customary practices bound up with the harvesting of coconuts, as well as a kinship-based system of inheritance.

The findings from this research are, in part, a reflection of the co-author's experiences relating to the management of the copra commodity while living in the village. Our work draws on the concepts presented by Roy Wagner in the book The invention of culture. For Wagner (1981), invention is, itself, a cultural process. Through the process of fieldwork, the anthropologist rediscovers his own culture and through in-depth encounters with his research subject, he can then discover the culture of his research subject.

\section{THE "GIFT" AND "COMMODITY" IN ANTHROPOLOGICAL CONTEXT}

Chris Gregory is one anthropologist who has provided a systematic discussion of gifts and commodities in his book, Gifts and commodities. Gregory (1982: 24) situates the concept of the "gift" alongside the concept of the "commodity" within political economic theory. He argues that the concepts of the gift and the commodity constitute two different but complementary concepts, representing distinct modes of exchange. As he sees it, commodities presuppose the existence of "reciprocal independence and alienation", while gifts presuppose the existence of "dependence and inalienability". In the exchange of commodities, the owner of a good becomes alienated from that good. However, in the exchange of commodities, actors are not interdependent. They are independent actors, free to determine with whom they will make an exchange. In the exchange of commodities, the relationships formed are relationships between objects of exchange.

What, then, of gifts? Gift exchange presupposes a relationship of 
interdependence between actors and that participants in the exchange are not alienated from the object exchanged. Why is this so? In gift exchange, the relations formed are relations between subjects, not objects, of exchange. For the donor, the very purpose of making the exchange is to build a relationship with the recipient of the object. Gregory (1982: 41) suggests that, in the exchange of commodities, both people and objects assume the social form of the object, while, in the exchange of gifts, objects and people assume the social form of people. Commodity exchange results in a process of objectification, while gift exchange results in a process of personification.

In her article, "Sorting out commodities; How capitalist value is made through gifts", Tsing (2013) also mentions Gregory's discussion of "commodities" and "gifts". By distinguishing gifts from commodities, Tsing creates space in which to explore the social relationships which exist beyond and through capitalist relations. Tsing, however, does not focus specifically on either the gift or the commodity, but rather the concept of "value". She begins her analysis with the question: "How do commodities become valuable?" In her research on Matsutake mushrooms in America, China, and Japan, she has found that what determines the commodity's value is not the commodity itself. It is, instead, gifts which shape the value of the capitalist commodity. The commodity is, therefore, incredibly dependent on non-capitalist social relations. Tsing (2013:21) writes, "Capitalist commodities thus come into value by using - and obviating - non-capitalist social relations, human and nonhuman". Applying the term, "primitive accumulation", originally coined by Marx, Tsing (2013: 21) argues that, "Capitalism does not transcend primitive accumulation but continues to depend on it". By seeing the connections between commodities and gifts, Tsing draws a conclusion different to that of Gregory - that gifts are a prerequisite for the production of commodity value. The value of the capitalist commodity is determined by forms of noncapitalist value.

As the discussion of these two concepts (gift and commodity) has developed, several anthropologists, including Jonathan Parry, have begun to critique the ideas put forward by Gregory. In his article Parry (1989: 64) criticizes Gregory for seeing gift and commodity exchange as always homogeneous and always in radical opposition. Gift exchange indicates the existence of a moral presence within the exchange, whereas commodity exchange indicates the opposite. The results of Parry's research in the city of Banares, India, suggest something different: the exchange of gifts in the form of money holds a moral peril. Money given to the priests in Banares as gifts by pilgrims becomes alienated from the donors because the gift is unreturned; these gifts of money become economic capital that the priests accumulate for themselves.

\section{MASOHI AS GIFT}

Ellen (2003: 126-131) implicitly interprets the sosolot institution as a system of mutual aid among neighbours and relatives, particularly useful in building 
homes or in the undertaking of various other social activities, while Bartels (2017: 245) defines masohi as an idealized Moluccan expression of a collectivist form enacted through many everyday tasks. In our opinion, the definitions of masohi put forward by Ellen and Bartels are inadequate. Masohi does not only involve relatives and neighbours as described by Ellen, it also extends to friends. Bartels's definition does not describe the reciprocated nature of efforts supplied through masohi work. Therefore, for the purposes of this article, we need to formulate a new definition of masohi which can guide our understanding of how copra farmers in the island of Seram have used this tradition. For us, masohi is a tradition of community work in Maluku (which includes the Island of Seram) which is based on non-capitalist social relations and the principle of reciprocal exchange. To clarify this definition, we provide the following illustration:

A is producing copra. The initial step in copra production is pameri (clearing the grass) for the coconut grove. He plans to do this work using masohi. A invites B, $\mathrm{C}$ and $\mathrm{D}$ to engage in masohi to complete the pameri of his coconut grove. During pameri, A provides food, cigarettes and breakfast. This work is finished within one day (8:00 a.m. to 6:00 p.m.).

A few days later, B dismantles the roof of his house and replaces it with a new roof. When A hears that B is going to replace his roof, he heads straight for the latter's house, even though he had planned to go to his coconut grove that day. A cancels his plan to go to the grove so that he can help $\mathrm{B}$ replace his roof. $\mathrm{C}$ and D are not involved in the masohi work of changing B's roof, but E, F, G, and A are. In the same coconut harvesting season, $\mathrm{C}$ is also working on copra production. $\mathrm{C}$ takes coconuts which have already been picked and are ready to be split back to the village in order for the coconut meat to be removed from its shell. $C$ does this in front of his house at night. $\mathrm{C}$ invites $\mathrm{A}$ and a few other people to help him with this work. Although A has just returned that afternoon from his garden, A will still come to C's house that evening to split the coconuts.

Drawing on the above illustration, we would like to note a few things as they relate to elements of masohi and the anthropological study of the gift. Firstly, when B, C, and D are involved in A's masohi work, what they provide A with does not consist of goods but, of a labour supply. Secondly, although $\mathrm{B}, \mathrm{C}$, and D know that A's work involves commodity production which will yield money, B, C, and D do not request wages for the work they do to support A. This demonstrates that the social relationships involved in masohi work are not capitalist relations. Thirdly, the involvement of B, C, and D in A's work makes A dependent on $\mathrm{B}, \mathrm{C}$, and $\mathrm{D}$ so that he $(\mathrm{A})$ is obligated to reciprocate the work they have provided. Fourthly, A does not necessarily remember the type of work with which B, C, and D have supplied him but, instead, which individuals were involved. So, when $B$ and $C$ have their own work needs, which are different from A's (with which they were involved), A still has a moral obligation to help B and C. Fifthly, B, C, and D are not alienated from the work with which they provide A because A will always remember the 
labour that they expended, which will be returned in the same or different form when, later, they have work to be done through masohi.

This definition and illustration demonstrate how masohi can be categorized as an anthropological gift.

\section{MONEY AS AGENCY}

The dual role of money which we mentioned earlier in this essay encourages us to see "money as agency". We borrow the concept of "money as agency" from George Simmel. In his book, The philosophy of money, Simmel (1978) sees money as a form of agency which encourages transformation in people's lives. Parry and Bloch (1989: 4) also present this idea:

Simmel saw money as an active agent which constitutes 'the major mechanism that paves the way from Gemeinschaft to Gesellschaft. [...] money itself as the principal catalyst fo the transformation of social life [...].

Money can act as both subject and object. It can be used as a medium of exchange, a commodity, a symbol or an object of exchange. Money can also influence people; an "intentionality" occurs between people and money. The interplay of influences between people and money does not occur at the point of first contact between the two but, rather, through a long and complex process, which occurs across space and time. Money assumes the form of a subject when it influences people and an object when people make use of it for various purposes. If we refer to Simmel's view above, money has an intrinsic power to encourage transformation in social life. In our view, money does not only incite such change, but it can also strengthen existing social relationships or, even, create new ones. We therefore see the role of money's agency not merely as functioning in change, as suggested by Simmel, but in many other forms, as we show below (Sections C and D).

\section{ACCEPTING THE COPRA COMMODITY, PRESERVING THE MASOHI TRADITION}

\section{A. DeVELOPMENT OF VILLAGE AND CITY FARMS USING THE MASOHI METHOD}

At the beginning of the twentieth century, the government of Sepa opened a village coconut farm in the coastal areas bordering the village of Rutah. This area was referred to as "Totun" or "Tanjung" (in English, meaning, 'peninsula') but, after the area was covered with coconut palms, its name changed to "Tanjung Yainuelo". In the local language (Sepa), the word yainuelo consists of two words, yai, which means 'timber' or 'tree', and nuelo, which means 'coconut'. The area encompassed by this coconut grove served as a precursor to the village Yainuelo, commonly referred to as Tanjung Yainuelo village. The community later responded to an increase in the price of copra and a high market demand for the commodity by expanding the coconut cultivation area. Rasyid Asba (2007: 43) notes: 
The copra product is Maluku's largest export. From 1928-1930, copra exports reached a total of 3 million rix-dollars. ${ }^{3}$ Local and international market demands for copra made coconut farmers in the Thousand Islands area expand their area of cultivation.

What is interesting about this coconut grove is that this land was neither privately nor family owned. As we have explained, the plantation was owned by the village. The coconut palms there were planted by members of the Sepa community observing the masohi system and, as the area of the grove was extended, also by several Butonese families who resided in the area. In the early stages preparatory to the planting process, members of the Sepa community took turns working to clear the forest in order to create a planting area. Each adult was obligated to be involved in these village farm activities; however, as it was an obligation, involvement did not result in any compensation.

At first glance the masohi work above does not show any signs of explicit reciprocity. The recipient of the masohi work was not a person but the village, which could not possibly provide remuneration. But does this prevent us from considering this masohi as a system of gift exchange? We are convinced that answering this question requires a fairly complex response to the issue of money. The labour provided by the people involved in the village farm masohi work does and did not alienate them from what they have given. Additionally, there is an implicit dependency between the labourer and the village government. The labourer, as a resident of the village, relies on the village government for certain needs as a local resident, including the issuing of government IDs, marriage licences, certificates of good conduct and the like. As a member of the village, each person involved in masohi work feels that the efforts they expend are obligatory. Although there is no obligation for the beneficiary to return the gift, there is still an expectation that the beneficiary will give the provider of labour something in return.

The masohi work model described above resembles the model of the gift which Mauss (2002) categorizes as "gifts to gods". When something is given to God, God has no obligation to return the gift and yet the giver hopes God will give him something in return. In his discussion, Mauss writes, "Gifts to men and to gods have the further aim of buying peace". Mauss argues that this gift-giving model is the predecessor of yet another theory, that of contractual sacrifice.

The relationship between gift (masohi) and commodity (copra) exchange is not merely complementary, as Gregory suggests, but actually demonstrates the commodity's dependency on the gift. This phenomenon affirms Tsing's assertion discussed above: the capitalist commodity heavily relies on noncapitalist social relationships. However, we are not yet convinced. The opaque distinctions between gift and hadiah modes of exchange in the two cases above are not clear enough for us to declare that these two modes as the same. EU. 
As mentioned, several Butonese families were involved in planting coconut palms during the expansion of the village farm. In this expansion phase, the work carried out was different to that required during the initial stage. The people who were involved in planting the coconuts were allotted a proportion of the coconut palms. Consequently, thereafter these families owned their own plots in the village coconut grove. The confirmation of this fact demonstrates its own unique complexity in the creation of the village coconut grove. The Sepa village government treated those involved in masohi work during the early stages of creating the farm differently from those, the Butonese, involved during the expansion phase. What motivated this decision? Several reasons suggest themselves to us. Firstly, the Butonese who participated in planting the coconut palms were recent residents of Sepa village and therefore had no land of their own to farm. Giving them a coconut plot was tantamount to presenting them with a livelihood. Secondly, control of resources in Sepa is assessed by tree, rather than by land. Whoever clears the forest and subsequently plants a crop on the land owns it. Given this fact, it is no longer a surprise that in Sepa a field owned by A might contain a few trees owned by B and a few more trees owned by $\mathrm{C}$.

Land is considered shared property and, therefore, giving space on one's farm to another person on which he can plant something is customary practice. Typically, people who employ this method of planting are relatives or people involved in helping with the work on the owner's land. In this way daily, collective work can create or strengthen social relationships.

Yainuelo village is located not far from the town of Masohi, lying just 20 kilometres east of it. Masohi is a town inaugurated by Soekarno in 1957, just after Indonesia's independence. The name bestowed on it, masohi, indicates the working tradition which the people used to bring it under cultivation. This history demonstrates how deeply the masohi tradition is entrenched in the lives of the people of Seram Island.

\section{B. MASOHI CLEARED THE LAND}

The distance between the villages of Yainuelo and Sepa is around 12 kilometres. A visitor to the area will see a vista dominated by coconuts between Yainuelo and Sepa villages. There scarcely a piece of flat land which has not been planted with coconut palms. After all the land for these coconut groves had been cleared, the palms were earmarked for the production of copra. At the same time as the village coconut grove was being set up, between the 1930s and the 1970s, community members were pursuing the same course - clearing the forest to plant coconut palms.

There were two ways of undertaking this work: it could be done by the owner of the field and his children or he could opt to ask for masohi. In this article, we are dealing with land cleared by using masohi. This second working method involved family members, neighbours and friends. When forest was to be cleared, the person planning to plant his grove would usually invite the people who were likely to be involved in masohi to help him. When he issued 
the invitation, there would have been no talk in which the labour provider set the conditions for the labour beneficiary to return the favour. This is the way masohi works; everyone involved does so sincerely and within the limits of their capability. Using masohi to clear forests in order to create groves or farms was already an accepted societal custom. Clearing forest to create other kinds of agriculture, apart from coconuts, was also accomplished in the same way.

In this case, the beneficiary of the masohi labour was not so much interested in what was given but, rather, in who provided it. Then as now the emphasis was on reciprocation. The labour beneficiary did not need to reciprocate the provider's labour in clearing the forest with identical work. Instead, the reciprocated work could take the shape of whatever the original labourer happened to be busy with. For example, after clearing the forest, several days later one of the people involved in masohi work might be building his house. The original labour beneficiary would reciprocate the masohi work by lending his labour in the construction. Villagers did not tally how much energy had previously been expended but, rather, who had given the gift. Gregory (1982: 19) writes, "[...] gift exchange establishes a relationship between subjects". Reciprocating each other's gifts strengthened the relationship between donors and would continue in the form of other reciprocated daily work. This circumstance has led Gregory (1982: 19; see also Andrej Rus 2008: 83) to refer to the gift economy as a debt economy.

Sahlins (1972) does not see the relationship between gift giver and recipient in the same light as Gregory, who considers it a highly moral relationship. Sahlins argues that the gift giver does not give the gift insincerely or indifferently, nor does he intend to profit from the gift. In his book Stone age economics, Sahlins (1972) refers to this as "generalized reciprocity". When we asked an informant of ours, "What made you get involved in masohi work?", he answered, it was because helping a person (with masohi work) would undoubtedly lead that person also to help him. However, as we have already stated this assumption of reciprocity is not explicitly articulated when masohi is enacted.

\section{COPRA PRODUCTION}

During copra production, masohi work was not confined to the land-clearing stage, but also extended to various other sorts of tasks. Technically, the copra production process can be divided into four stages. The first of these is pameri. Pameri is a term that the people of Yainuelo and Sepa use to refer to activities related weeding the coconut grove. After a coconut grove has been harvested, it will usually be left undisturbed for a period of three months. As a consequence, the weeds run riot under the coconut palms, until the farmers eventually return to clear the weeds, prior to harvesting season. A grove owner usually undertakes pameri by himself, but he can call on masohi help to complete the task.

Secondly, coconuts are harvested by climbing up the coconut palms. The owner of the coconut grove and his children usually do the climbing 
themselves, but they can invite other people to do it. Involving other people in tree-climbing requires resorting to the custom called sewa; people refer to it using the term sewanai. The cost of sewa coconut climbing is calculated per tree and a distinction is made between low and high trees. The work of climbing trees to pick coconuts was rarely done by masohi. When masohi was used, it was only in groves in which small coconut palms grew; those no higher than about 15 to 20 metres. Those involved in sewanai are not responsible for gathering the coconuts which fall. The owner of the field does this as the coconuts are being plucked from the tree. The charge for sewa is usually recompensed immediately after all of the coconut palms have been harvested. In certain cases, people ask for their sewa money in advance, before they scale the coconut palms; this practice is commonly referred to as bayar panjar.

Who usually climbs the coconut palms under sewa terms? The answer to this question is not simple. There are various reasons the owner of a grove might not simply ask any person to climb his coconut palms. The sort of person who usually does this work is not someone who owns a coconut grove or, if they do, at the time of the coconut harvest, it is not his turn to work the coconut palms in an inherited field. The majority of the people who take on this work are Butonese.

The third phase is the work of splitting coconuts and sisi kelapa (removing the flesh from the coconut shell). These two activities are always done simultaneously or spread out over 8-10 hours. Although the individual who manages the copra usually does the work of splitting and removing the flesh himself, it can also be done through masohi. If performed individually, the work is typically undertaken in the grove in which the coconuts have been picked. However, if the work is to be done using masohi, the coconuts are brought back to the village. The masohi work of splitting the nut and removing its flesh is usually done in the evening. On their own initiative, family and friends come to the place at which the coconuts are piled up and busy themselves in this work. The copra manager prepares drinks, cake and cigarettes for the participants. The atmosphere is lively because people do come not just to work but also simply to chat.

The fourth process is drying the coconut flesh. The desiccation process depends on the season. If the copra-producing process occurs during the rainy season, the copra manager will create a place at which the flesh can be smoked. Coconut flesh which has already been removed from the shell is laid in this place for one to two days. However, if the process of managing the copra occurs during the dry season, the smoking is discarded and the flesh is dried in the scorching sun. The copra manager, helped by his children, performs this work alone.

Henry Bernstein (2010) refers to the production of commodities as "petty commodity production". In formulating his concept, Bernstein sees the farmer as the owner of capital, as well as a worker for himself. This system of work is based on kinship and friendship, much like masohi work in copra management. However, this still begs the question: Why was masohi used for 
copra production when it is clearly a capitalist commodity? To answer this, we return to the understanding of masohi suggested by Bartels. Masohi is an idealized collectivist expression of many everyday tasks. When the people of Sepa first became familiar with copra, they were aware that producing this commodity would generate them cash. However, they did not immediately understand the logic of work intrinsic to the commodity. Still in ignorance of this, they treated copra commodity production like working on any other daily activity using methods not supported by a capitalist logic.

This realization brings us to the process of "continuity in transformation" described by Sahlins (1981), Valeri (1994), and also the author of this article (Rudyansjah 2009). As it was a novelty process, they did not understand the copra commodity through the logic of a commodity but through their preexisting concept of economy. Sahlins refers to this as "cultural continuity". Cultural continuity is a way by which people interpret and respond to a new event using pre-existing systems of categorization. This continuity occurs precisely at the point of transformation and, conversely, this transformation occurs when there is continuity. As Gregory suggests, transformation does not occur without continuity.

At this stage of commodity production, masohi work demonstrates a paradox. After passing through several lengthy stages of work, copra becomes a commodity ready for exchange on the market. Consistent with the dimensions of commodity exchange suggested by Gregory, copra exchange alienates the farmers who sell the product from the product itself. The buyer will exchange money for the product and, after this, the relationship between the farmer and the buyer is terminated. However, copra which has already been sold on the market leaves behind a relationship of debt between the farmer and the people involved in masohi work from the time of copra production.

Several days after changing hands, this copra might already be stored in warehouses in Surabaya or even Europe, or already be processed and converted into a new product by machines. And, yet, the relationships formed during its production persist. Therefore, in our situation commodity exchange is not as simple as Gregory asserts, as it assumes the reciprocal independence and alienation of exchangers. In real life situations, this dynamic is more complex. Farmers do not sell copra to large-scale traders but rather to small-scale traders in their villages. These small-scale traders are typically Butonese, Buginese, Chinese, or Arab and function as collectors or aggregators. The relationship between the farmer and the village collector creates new relationships of dependence and debt, which are an extension of relationships of commodity exchange. These relationships of dependence are different from the relationships of dependence created through masohi work. These small-scale traders will provide farmers with cash, thereby creating a debt. When coconut harvesting season arrives, the farmers will pay off this debt by supplying the small-scale trader with copra. This kind of relationship is formed not only for copra but also for other commodities like cloves, nutmeg and pepper (see Otto Hospes 1996; Kadir 2014). 
Therefore, money, as a medium of exchange or commodity does not necessarily destroy the fabric of social relations, rather it might create, as in a certain historical context in Yainuelo, a new form of social relation and solidarity. As we mention in the Introduction, ambiguity pertains not only to gift, but also to money or commodity.

\section{Money AS A REASON FOR COPRA ACCEPTANCE}

Molucans had become acquainted with money long before they were familiar with copra. In the fourteenth century, when cloves and nutmeg became global commodities, Molucan traders were already connected with the world trade system (see Ellen 2003). Ellen refers to this period as, "Moluccan trade in the world system". In the eighteenth century, other commodities began to replace cloves and nutmeg as global commodities. This had a significant impact on Molucan farmers. The production of copra as a commodity provided farmers with a fresh opportunity to increase their cash income.

Farmers originally did not produce copra as a commodity in order to amass it for their own use but, rather, to obtain something which could be used to fulfil their various needs. Money was that answer to meeting their needs. In the early era of copra acceptance, money was used to meet only a few needs, like funding the Hajj pilgrimage. Bartels (2017: 312) argues that the importance of the Hajj pilgrimage to Muslims in Maluku led a group of Molucans to create a holy land of Mecca on their own land. As followers of Islam, the people of Sepa dream of becoming a hajji. If we were to ask the elderly, those who had performed the fifth pillar of Islam during the twentieth century, how they obtained the money to visit the Holy Land, they would answer from copra and clove earnings.

In the eyes of the family members involved in masohi, the work they gave was part of fulfilling a moral duty so that their parents and relatives could observe this fifth pillar of Islam. However, the intention of neighbours or friends involved in masohi work was to benefit from reciprocation of their work. In order to accumulate enough money to fund the Hajj pilgrimage, a coconut grove could be rented to another person for 5-10 years. Family members did not object to this because, from the earliest days of copra commodity production, copra had been intended to meet this need.

\section{CHASING MONEY, LEAVING MASOHI BEHIND}

What caused the use of masohi traditions in copra management to change? Over time, people's energy was increasingly diverted into various schemes which could generate cash. Hence, they had little time left for work which did not earn them an income, like masohi. Introducing copra as a commodity meant commodifying coconut palms, turning them from a subsistence crop into an income-generating tree. The commodification of this tree triggered an increase in the circulation and growth of cash in the social life of copra farmers, a process Kadir (2014) refers to as "monetization". This monetization of the lives of copra farmers caused both conceptual and physical transformations in relationships 
among people and in the relationships between people and nature. Masohi, as a tradition of reciprocated work based on non-capitalist social relations which generates subsistence capital, is gradually being abandoned because it does not generate money. It is being replaced by a work tradition based on wages.

How have transformations in the masohi tradition, as applied to copra commodity management, played out in everyday practice? To answer this question, we commence by pointing out events in the changing landscape of the coastal ecology in Sepa. Clearing land for coconut cultivation originally took place on the coastal plains between Yainuelo and Sepa. Initially, the majority of these flat areas were covered with sago fields. In other words, clearing land for coconut cultivation displaced sago fields. Sago was one of the main sources of food for people on Seram and, therefore, the displacement of sago fields inevitably had the effect of depleting the people's subsistence food source. In the edition of the newspaper Kompas on 27 February 2018, Ahmad Arik notes that land allocated to sago in Maluku has shrunk by up to 50 percent over the past fifty years. The long-term effect of destroying sago fields is that the households of copra farmers must now spend cash in order to buy the staple food, no longer sago but rice. Hence, the need for cash is increasing.

Up until the 1990s, some people had, in fact, only consumed rice on special occasions, like Fridays or during Lebaran. The change in consumption from sago to rice did not occur immediately coconut palm cultivation displaced land dedicated to sago but was a long, multi-factorial process. Even though the sago fields near Yainuelo village were taken over in the 1960s, people from this village in Sepa continued to obtained sago from other areas. Meanwhile, the Butonese and people from Kei were still consuming cassava as their staple food. In addition to sago, the people of Yainuelo also ate cassava as a subsistence staple. In short, the people in Sepa ate cassava in lieu of sago before, later, shifting to rice.

The second question we want to try to answer is why was it not until the era of the 2000s that sago was significantly abandoned as the staple food? As we have argued, this change occurred because of several additional factors, one of which was education. From the time they began to attend primary school, school children in Maluku were introduced to rice-fields and rice. One reading exercise, for example, runs, "This is Mr. Budi. Mr. Budi goes to the rice-fields. This is Mrs. Budi. Mrs. Budi cooks rice in the kitchen". The earliest knowledge imparted to primary school children participating in formal education is about rice-fields and rice, even though the students there had never seen a rice-field and rarely ate rice. This altered their perspective on food. These lessons were constructed to re-imagine rice, not sago, as a good food.

In 2000 (when the co-author was still in junior high school), he met a family who lived in another village. He arrived close to lunch-time and was invited to eat with this family. No rice was served on the table; there was only sago. When he saw the food which was being served, he thought to himself, "This family is still poor". Reflecting back on this event, we might ask, "Why, at a fairly young age and not yet widely read did he already entertain ideas like 
this?" He had become attuned to the ways in which the texts frequently read in primary school cultivated this kind of knowledge. In his eyes, sago had become a poverty marker. So as not to be thought poor, he avoided learning how to prepare and cook sago to eat from his parents. In his mind, the right and proper food to eat was rice. This despite the fact his parents did not know how to cultivate rice-fields and the geographical conditions in his village made rice-fields an agricultural impossibility.

So, how could he continue to eat rice? The answer: by buying rice. To meet his family's daily carbohydrate intake, a copra farmer must spend between IDR 15,000 and 20,000 on rice. Hence the need for cash increases. These circumstances impacted on the organizational system for the work involved in the management of copra. Consequently, masohi work is now almost just a memory because people prefer working for cash, which can be used to meet the family's daily food intake.

The third factor driving change is the number of children pursuing further education in the city and becoming employees of government agencies. The majority of parents in villages hope their children will be awarded a bachelor's degree or become civil servants so that, as they say, their children will not experience the same hardship they have had to endure. Children who have not been to the fields for a while have undergone physical changes, meaning that many of them are no longer able to do heavy work. Many children in this category no longer have the capacity to fulfil the masohi traditions for certain kinds of work required for the production of copra. The desire to become a civil servant stems primarily from the hope of receiving a monthly salary, as well as the recognition and prestige which accrue from holding such a position. Money, again, returns as an important aspect in the transformation of masohi.

\section{CONCLUSION}

In conclusion, we are reminded of the story of Captain Cook in Sahlins's history of Hawaiian society, Historical metaphors and mythcal realities; Structure in the early history of the Sandwich Islands Kingdom. Captain Cook's acceptance by Hawaiians causes unintentional transformations in their social structure. These transformations take place through incredibly complex processes and relations. Referring to such circumstances, the author (Rudyansjah 2009: 40) writes, at such moments of transformation, culture is re-created according to the events and interests of each historical actor. This, too, is what has happened in Yainuelo village.

The accidental acceptance and introduction of copra as a commodity, a process involving various actors participating in complex relationships, has already brought drastic changes in the social relationships in the Sepa and Yainuelo communities. When first introduced, copra was considered a way to earn enough money to enable farmers to meet specific financial needs (for example, for the Hajj pilgrimage) and to emphasize their piety. Eventually it ultimately turned into a fetish. Even though a desire for money motivated the creation of copra plantations, initially people were still living in a subsistence 
economy. However, the infiltration of money gradually changed the farmers' mentality from that of money utilizers to that of money chasers. Social relationships which had developed through involvement in collective work in the daily sphere were replaced by the exchange of money.

Masohi, as a centuries-old tradition of collective work in the lives of the Molucan people, has eroded, abandoned less than a century after farmers first became acquainted with copra as a commodity. With money, say Saluang et al. (2015: 81), the ethos of the mode of production changes from an essence of self-sufficiency to an attempt to achieve the greatest comfort possible, above all physical comfort. In a nutshell, in the end money itself changes from merely a medium of exchange to a kind of agency; money which was once passive transforms and becomes an active actor. It is this transformation which has entailed profound consequences for the people of Yainuelo village.

\section{REFERENCES}

Asba, Rasyid. 2007. Kopra Makassar perebutan pusat dan paerah; Kajian sejarah ekonomi politik regional di Indonesia. Jakarta: Yayasan Obor Indonesia.

Bartels, Dieter. 2017. Di bawah naungan Gunung Nunusaku; Muslim Kristen hidup berdampingan di Maluku Tengah. Jilid I: Kebudayaan. Jakarta: Kepustakaan Populer Gramedia.

Bernstein, Henry. 2010. Class dynamics of agrarian change. Bloomfield, Conn.: Kumarian Press. [Agrarian Change and Peasent Studies Series.]

Ellen, Roy. 2003. On the edge of the Banda Zone; Past and present in the social organization of a Moluccan trading network. Honolulu, HI: University of Hawai'i Press.

Gregory, Christoper A. 1982. Gifts and commodities. New York, NY: Academic Press.

Hospes, Otto. 1996. People that count; Changing savings and credit practices in Ambon, Indonesia. PhD thesis, Wageningen Agricultural University.

Kadir, Hatib Abdul. 2014. "Ambon di bawah Orde Baru; Transformasi kapitalisme pada masyarakat pinggiran". [Retrieved from: http:// satutimor.com/ambon-di-bawah-orde-baru-transformasi-kapitalismepada-masyarakat-pinggiran.php; accessed on 24-3-2015.]

Kadir, Hatib Abdul. 2017. Gifts, belonging, and emerging realities among "other Molucans" during the aftermath of sectarian conflict. PhD thesis, University of California Santa Cruz.

Mauss, Marcel. 2002 [1954]. The gift; The form and reason for exchange in archaic societies. London/New York, NY: Routledge Classics.

Parry, Jonathan. 1989. "On the moral perils of exchange", in: Jonathan Parry and Maurice Bloch (eds), Money and the morality of exchange, pp. 64-93. New York, NY: Cambridge University Press.

Parry, Jonathan and Maurice Bloch. 1989. "Introduction; Money and the morality of exchange", in: Jonathan Parry and Maurice Bloch (eds), Money and the morality of exchange, pp. 1-32. New York, NY: Cambridge University Press. 
Retsikas, Konstantinos. 2016. "The other side of the gift; Soliciting in Java", Heidelberg Ethnology, Occasional Paper 4: 1-16.

Rudyansjah, Tony. 2009. Kekuasaan, sejarah, dan tindakan; Sejarah kajian tentang lanskap budaya. Jakarta: Rajawali Pers.

Rus, Andrej. 2008. "'Gifts vs. commodity' debate revisited". Anthropological Notebooks 14(1): 81-102.

Sahlins, Marshall. 1972. Stone age economy. London / New York, NY: Routledge Classics.

Sahlins, Marshall. 1981. Historical metaphors and mythical realities; Structure in the early history of the Sandwich Islands Kingdom. Ann Arbor, MI: University of Michigan Press. [Asao Special Publications No. 1.]

Saluang, Surya, Didi Novrian, Risman Buanona, and Meifita Handayani. 2015. Perampasan ruang hidup; Cerita orang Halmahera. Yogyakarta: Tanah Air Beta.

Simmel, Georg. 1978. The philosophy of money. London/New York, NY: Routledge \& Kegan Paul.

Tsing, Anna Lowenhaupt. 2005. Friction; An ethnography of global connection. Princeton, NJ: Princeton University Press.

Tsing, Anna. 2013. "Sorting out commodities; How capitalist value is made through gifts", HAU: Journal of Ethnographic Theory 3(1): 21-43.

Valeri, Valerio. 1994. "Buying women but not selling them; Gift and commodity exchange in Huaulu Alliance", Man, New Series 29(1): 1-26.

Wagner, Roy. 1981. The invention of culture. Chicago, CA/London: The University of Chicago Press.

\section{ABOUT THE AUTHORS}

TONY RUDYANSJAH completed his doctoral degree in anthropology from the University of Indonesia in 2008. He is now acting as the chairman of the Department of Anthropology at the University of Indonesia. His publications include Kekuasaan, sejarah, \& tindakan (Jakarta: Rajawali Pers, 2009), Alam, kebudayaan \& Yang Ilahi (Jakarta: Titian Budaya, 2011), Antropologi agama (Depok: UI-Press, 2012), and Emile Durkheim (Jakarta: Penerbit Buku Kompas, 2015). Tony Rudyansjah can be reached at: tony.rudyansjah@ui.ac.id.

ODE ZULKARnAin SAHJI TIHURUA completed his Master of Science in anthropology from the University of Indonesia in 2019. He is the founder of NGO sKOla RAkyat (KORA) in the Moluccas, Indonesia. His article entitled "Opini; Land Certification, a ticking time bomb", The Jakarta Post, 14 September 2018. Ode Zulkarnain Sahji Tihurua can be reached at: tihuruaz85@ gmail.com. 